\title{
THE CROSS-BORDER ENFORCEMENT OF COURT SETTLEMENTS WITHIN BRUSSELS IA REGULATION: FROM A EUROPEAN AND AN Austrian Perspective
}

Accepted

23. 10.. 2020

Revised

27. 11. 2020

Published

21. 12. 2020

UDC

347.952:347.469

(436:061.1EU)

Keywords court

settlement,

Brussels Ia

Regulation, cross-border enforcement, recognition,

scope,

judgment,

certificate,

exequatur.

\author{
PHILIPP ANZENBERGER \\ University of Graz, Institute of Civil Procedure and Insolvency Law, Graz, Austria. \\ E-mail: philipp.anzenberger@uni-graz.at \\ CORRESPONDING AUTHOR \\ philipp.anzenberger@uni-graz.at
}

Abstract Despite the enormous practical relevance of court settlements, the Brussels Ia Regulation contains only a few explicit provisions for the cross-border enforcement of this legal instrument. This can cause difficulties in borderline cases, for example when it is doubtful whether the legal act in question is to be classified as a settlement or a judgment or which specific European regulation is applicable to a settlement containing several different claims. This paper provides a general overview of the rules for the enforcement of court settlements under the Brussels Ia Regulation and examines some problems that may specifically arise in the case of cross-border enforcement of court settlements. 


\section{$1 \quad$ Introduction}

Court settlements are extremely practical instruments of amicable dispute resolution. In Austria, for example, about one-third of the approximately 80,000 civil proceedings conducted annually end with a settlement (cf. Anzenberger, 2020: 1). Consequently, the relevant regulations of European civil procedural law provide for the possibility of enforcing court settlements in other European Member States. To a large extent, these provisions are based on those concerning the enforceability of judgments; however, due to the peculiarities of the "court settlement" instrument, there are some significant deviations. This article has two objectives in this context. First, following a brief description of the relevant provisions and the changes introduced in comparison to the Brussels I Regulation, ${ }^{1}$ it will provide an overview of the enforcement regime for court settlements within the scope of the Brussels Ia Regulation. ${ }^{2}$ Second, following the outline of this overview, it will provide a more detailed analysis of some particular issues that may arise in connection with court settlements, including the definition of a court settlement (and its demarcation from a decision), the scope of the European Regulations with regard to extensive settlements, as well as the question of the possible recognition of court settlements.

\section{The relevant changes from Brussels I to Brussels Ia}

Before examining the issues mentioned above, it seems helpful to outline the differences between the Brussels I Regulation and the Brussels Ia Regulation with regard to court settlements. The changes are not excessive, especially since court settlements were not explicitly identified as a problem area either in the Commission's Green Paper, or in the Heidelberg Report or in the Proposal (cf. Dickinson and Lein, 2015: p. 14.33). The background documents do not explain these modifications; scientific literature assumes that they were instituted mostly due to the desire to clarify the provisions and because of the general changes in the system of enforcement in the Brussels Ia regime (Dickinson and Lein, 2015: p. 14.34).

\footnotetext{
${ }^{1}$ Council Regulation (EC) No 44/2001 of 22 December 2000 on jurisdiction and the recognition and enforcement of judgments in civil and commercial matters (OJ L 12, 16. 1. 2001, p. 1).

2 Regulation (EU) No 1215/2012 of the European Parliament and of the Council of 12 December 2012 on jurisdiction and the recognition and enforcement of judgments in civil and commercial matters (OJ L 351, 20.12. 2012, p. 1).
} 
First and foremost, there now is an explicit definition of court settlements in Art. 2(b) Brussels Ia Regulation. According to that definition, a "court settlement" is a "settlement which has been approved by a court of a Member State or concluded before a court of a Member State in the course of proceedings". This definition goes beyond the previous notion in Art. 58 Brussels I Regulation, according to which a "settlement which has been approved by a court in the course of proceedings" and is enforceable in the Member State in which it was concluded shall be enforceable in the State addressed under the same conditions as authentic instruments.

Secondly, the wording "shall be enforceable" (Art. 58 Brussels I Regulation) was changed to "shall be enforced" (Art. 59 Brussels Ia Regulation) in the English version of the Regulation. According to the literature, this is not a substantive change (Dickinson and Lein, 2015: p. 4.36); instead, this modification can be interpreted as a linguistic adaptation as a consequence of the abolition of the exequatur procedure. This hypothesis is reinforced by the fact that the German version of the Regulation ("werden ... vollstreckt") has remained unchanged in this aspect.

And finally, for the purposes of the certificate under Art. 42 Brussels Ia Regulation (which, according to the reference in Art. 58(1) Brussels Ia Regulation, needs to be produced when enforcing court settlements as well), Art. 60 Brussels Ia Regulation (instead of Art. 58 Brussels I Regulation) now refers to Annex II (instead of Annex V; cf. Kern, 2017: Art. 59 Brüssel Ia VO p. 3). Also, the form itself - apart from its renaming - has been significantly expanded in terms of content.

\section{Court settlements and the scope of Brussels Ia Regulation}

\subsection{The definition of a court settlement}

According to Art. 2(b) Brussels Ia Regulation, a court settlement is a "settlement which has been approved by a court of a Member State or concluded before a court of a Member State in the course of proceedings". As mentioned above, this definition was broadened in comparison to Art. 58 Brussels I Regulation and now leaves no doubt that it covers not only settlements that were reached in court during a proceeding but also settlements that were already reached out of court and rendered enforceable (as 
provided for in Art. 6 of the Directive ${ }^{3}$ on certain aspects of mediation in civil and commercial matters, for example; cf. Kern, 2017: Art. 59 Brüssel Ia VO p. 7; Kodek, 2014: Art. 59 EuGVVO p. 4). Still, the definition itself is quite vague and rather suboptimal from a legislative point of view. Not only is the term being defined actually used in the definition (thereby creating a circular logic), but also there are no positive criteria for identifying what legal acts may be considered a court settlement (cf. Frische, 2006: 137 on the same problem regarding the definition of a judgment). Some answers to these deficiencies can at least be derived from the case law of the Court of Justice of the European Union (CJEU), according to which "settlements in court are essentially contractual in that their terms depend first and foremost on the parties' intention"4.

The lack of a sharp definition may not be a problem in the majority of cases, because the concept of a court settlement is well-known in most Member States (although its concrete form varies between the different Member States and is highly controversial in some of them, e.g., Germany or Austria; (Klicka, 2015: \$\$ 204-206 ZPO p. 6-9; Staudinger, 2016: Art. 2 Brüssel Ia VO p. 21). From an Austrian understanding, for example, a court settlement is, "an agreement on the content regarding rights or legal relationships that is recorded in court" (Anzenberger, 2020: 87). In most cases this includes a procedural contract as well as a contract under substantive civil law (even though a civil contract is not necessary in many ${ }^{5}$ cases; cf. Anzenberger, 2020: 63-64). There are three main types of court settlements in Austrian law: the "classic" court settlement, which is concluded on the occasion of an ongoing procedure, the praetoric settlement (which - typically before the start of a legal dispute - can be concluded between the parties with judicial mediation before a district court) and the mediation settlement, which essentially puts the content of an agreement reached in a mediation procedure in the form of a (generally enforceable) court settlement. All three of these types of settlements are settlements within the meaning of Art. 2(b) Brussels Ia Regulation (as well as the definition of the CJEU) and thus fall under the regime of Art. 59 Brussels Ia Regulation.

\footnotetext{
${ }^{3}$ Directive 2008/52/EC of the European Parliament and of the Council of 21 May 2008 on certain aspects of mediation in civil and commercial matters (OJ L 136, 24. 5. 2008 p. 3).

${ }^{4}$ Case C-414/92, Solo Kleinmotoren GmbH v Emilio Boch, ECLI:EU:C:1994:221 (Solo Kleinmotoren).

5 This is a highly controversial question, however; according to the prevailing view the omission to conclude a

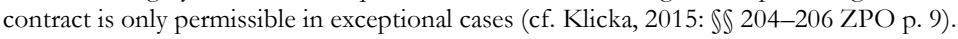


In some Member States, however, there are legal acts whose classification as a "court settlement" (Art. 2(b) Brussels Ia Regulation) or a "judgment" (Art. 2(a) Brussels Ia Regulation) is less obvious, for example the French jugement d'exdédient (Peiffer and Peiffer, 2016: Art. 2 VO [EU] Nr. 1215/2012 p. 10). According to Art. 2(a) Brussels Ia Regulation, a judgment is "any judgment given by a court or tribunal of a Member State, whatever the judgment may be called, including a decree, order, decision or writ of execution, as well as a decision on the determination of costs or expenses by an officer of the court". Again, this definition is not very informative (Frische, 2006: 137) and leaves quite some room for interpretation (although the examples used may give a certain impression of its content); this interpretation must - of course - be carried out autonomously (Neumayr, 2017: p. 3.902).

Scientific literature has proposed several possible standards that might be used in order to distinguish between a settlement and a decision. One such proposition is a mere formal distinction, according to which it should depend on whether the act in question takes the form of a judgment or a decision (von Hoffmann and Hau, 1995: 218; cf. Peiffer and Peiffer, 2016: Art. 59 VO [EU] Nr. 1215/2012 p. 6), in which case it should not be considered a court settlement. Another criterion proposed in the literature focuses on the functional role of the court, i.e. whether the court only documents the "court settlement" or examines it in the light of certain minimum legal requirements or whether it takes a decision on the substance (Kropholler and von Hein, 2011: Art. 58 EuGVO p. 1b). Finally, some authors propose a distinction based on the effects of the act in question, where "judgment-like" effects, such as a res indicata-effect, shall indicate that it is a judgment (Peiffer and Peiffer, 2016: Art. 59 VO [EU] Nr. 1215/2012 p. 9; Schulze, 2017: Art. 2 Brüssel Ia VO p. 20). From my point of view, the most important factor distinguishing a judgment and a court settlement is whether the legal act created is predominantly of a contractual nature (which also includes procedural contracts) or predominantly a sovereign decision (cf. Kropholler and von Hein, 2011: Art. 58 EuGVO p. 1a). This assessment takes into account both the formal form of the legal act and the functional role of the court. The effects of the acts in question, however, do not constitute a suitable criterion for delimitation in my opinion, not only because the effects of judgments - as well as of court settlements - may vary strongly in different Member States (and therefore there are no "exclusive" effects that determine when to consider an act a "judgment" or a "court settlement"), but also because court settlements constitute "judgment surrogates" in some legal systems, potentially generating the same legal 
effects as judgments. Following this understanding, if the court of law takes a sovereign decision, then - as a rule of thumb - this legal act is to be considered a "judgment" for the purposes of the Brussels Ia Regulation, even if it was reached by consensus in the proceedings (for example, if one party had admitted the claim or if the parties had largely predetermined the facts on which the decision is based). Accordingly, Austrian "judgments of recognition" ("Anerkenntnisurteil") or "judgments of renunciation" ("Verzichtsurteil") are to be classified as "judgments" in the sense of Art. 2 lit. a Brussels Ia Regulation (Brenn, 2010: Art. 58 EuGVVO p. 2).

\subsection{Court settlements and the scope of the Brussels Ia Regulation}

Court settlements may also cause some specific problems with regard to the scope of the Brussels Ia Regulation (which itself shall not be further discussed here). It is quite common for court settlements to regulate rights and legal relationships which, if settled separately, would fall within the scope of different European regulations (Anzenberger, 2020: 143-144). For example, according to Austrian law, one single court settlement could include claims arising out of a car accident as well as maintenance claims from a son against his father. In these cases, it is necessary to clarify which rules for enforcement (and possibly even recognition ${ }^{ø}$ ) apply.

As long as the respective rights and legal relationships can be separated (for example because they are listed individually in the court settlement), each claim should be assigned to the corresponding European Regulation and subjected to the respective enforcement regime (cf. Brenn, 2010: Art. 58 EuGVVO p. 5; Geimer, 2020: Art. 59 EuGVVO p. 9; Staudinger, 2016: Art. 59 Brüssel Ia VO p. 27). This goes hand in hand with the possibility of partial recognition and partial enforcement of judgments within the scope of the Brussels Ia Regulation (Kodek, 2014: Art. 36 EuGVVO p. 31; Leible, 2016: Art. 36 Brüssel Ia VO p. 14); the fact that the court settlement is a single formal "vessel" for these claims cannot make a difference in this aspect. What is more complicated, is a situation in which the claim that is the subject of the settlement does not fall under the auspices of one single regulation, for example where the payment of a single sum of money was agreed on the basis of two different original claims (i.e. in the above example, claims arising from a car accident and

\footnotetext{
${ }^{6}$ Cf. Chapter 5.

${ }^{7}$ Staudinger makes this statement indirectly by saying that this problem only arises where the claims cannot be separated into areas.
} 
maintenance claims). In this case, it has been suggested in the literature that what regulation applies should depend on the "main emphasis" of the settlement in each individual case (Staudinger, 2016: Art. 59 Brüssel Ia VO p. 2). If there is no clear main emphasis, according to some authors, the more specific regulation should be applied (Mankowski, 2016: Art. 1 Brüssel Ia VO p. 49; Staudinger, 2016: Art. 59 Brüssel Ia VO p. 2), which - according to this opinion - could be methodically achieved by a generous interpretation of the exceptions in Art. 1(2) Brussels Ia Regulation (Mankowski, 2016: Art. 1 Brüssel Ia VO p. 49). Although in some cases these proposals will lead to satisfactory results, in others they also raise problems of demarcation. For example, situations may occur where it is not apparent that there is any claim that forms the main focus of the settlement. There will be other situations where it is not clear which European Regulation is the "more specific" one. In my opinion, it would be more consistent simply to assume the emergence of a new civil claim in cases where the original claims are "blended beyond recognition". This new civil claim would then - in the absence of a specific legal nature - fall within the scope of application of the Brussels Ia Regulation (cf. Art. 1(1) Brussels Ia Regulation). From the parties' point of view, this should not cause problems since, if they wish to retain the enforcement regimes provided for the original claims, they can structure the settlement according to their own ideas (and therefore formulate the claims in a separable manner).

\section{$4 \quad$ Legal framework for the enforcement of court settlements}

\subsection{Enforceability in the Member State of origin}

According to Art. 59 Brussels Ia Regulation, the main requirement for the enforcement of a court settlement is its enforceability in the Member State of origin. This corresponds to the legal situation regarding judgments (cf. Art. 39 Brussels Ia Regulation) and, in my view, should be interpreted accordingly. Enforceability means "abstract enforceability" (Neumayr, 2017: p. 3.926), so if, for example, the enforceability of the court settlement depends on the provision of security or an offer of a service in return in the Member State of origin, then this is also a prerequisite for enforceability in other Member States. The lack of "concrete" enforceability (for example, if the debtor has no assets at all or no assets in the Member State of origin) however, is irrelevant to the question of "enforceability in the Member State of origin" (Kodek, 2014: Art. 39 EuGVVO p. 16). As with 
judgments (cf. Kodek, 2014: Art. 39 EuGVVO p. 8; Mankowski, 2016: Art. 39 Brüssel Ia VO p. 51), the question whether the settlement remains open to challenge or not is also independent of the requirement of enforceability in the Member State of origin; even provisional enforceability must be sufficient.

\subsection{Certificate according to Art. 60 Brussels Ia Regulation and other modalities of enforcement}

Art. 59 Brussels Ia Regulation stipulates that court settlements shall be enforced in the other Member States under the same conditions as authentic instruments; therefore, Art. 58(1) Brussels Ia Regulation (which refers to Chapter II Section 2, Section 3 Subsection 2 and Section 4 of the Brussels Ia Regulation on the modalities of enforcement) applies to court settlements as well. The literature is critical of the fact that it is not necessarily self-evident which of the provisions of the mentioned sections could be applied to court settlements (Dickinson and Lein, 2015: p. 14.43); however, these authors convincingly assume that the provisions of Art. 41-44 and Art. 46-50 Brussels Ia Regulation are generally applicable.

According to Art. 41(1), in conjunction with Art. 59 Brussels Ia Regulation, the law of the Member State of enforcement is also applicable to the enforcement of court settlements. When applying for the enforcement of court settlements, the applicant must submit both a copy of the settlement (Art. 42(1)(a) Brussels Ia Regulation) and a certificate according to Art. 60 of the Brussels Ia Regulation (which can be found in Annex II of the Regulation). The form in Annex II contains information pertaining to both the issuing court (point 3 of the form) and the parties (point 4 of the form), as well as some more detailed information (in comparison to the very rudimentary form $\mathrm{V}$ of the Brussels I Regulation) on monetary claims (point 5.2.1 of the form). This is important, because in many cases it makes a translation, which may be required by the enforcement authority under Art. 42(2) Brussels Ia Regulation, unnecessary. However, the situation is different for non-monetary enforceable obligations; here, only the heading "short description of the enforceable obligation" is included (point 5.2.2 of the form), which in most cases will probably not be enforceable without further translation. Also, the form must indicate whether the court settlement is enforceable in the Member State of origin (point 5.1 of the form). Translations of the settlement itself as well as of the certificate must be 
submitted in accordance with the provisions of Art. 42(4) Brussels Ia Regulation and Art. 43 Brussels Ia Regulation.

\subsection{No more exequatur but refusal of enforcement in the case of public policy infringements (ordre public)}

Due to the explicit wording of Art. 58(1) Brussels Ia Regulation (creating a parallel with the provisions on judgments), there is no longer any need for a declaration of enforceability for court settlements. Instead, court settlements are to be enforced directly in any Member State upon presentation of the certificate in Annex II. The abolition of the exequatur procedure, however, does not mean that no objections to enforcement can be raised. In contrast to judgments, however, only the infringement of public policy (ordre public) can be raised as a ground for the refusal of enforcement of court settlements (Art. 58 Brussel Ia Regulation); the other grounds for refusal according to Art. 45 Brussels Ia Regulation do not apply (Peiffer and Peiffer, 2016: Art. 58 VO [EU] Nr. 1215/2012, p. 22). This is, by the way, the system-derived reason for the prevailing opinion that the jurisdictional regime in the Brussels Ia Regulation does not apply to court settlements (Brenn, 2010: Art. 58 EuGVVO p. 5; Geimer, 2020: Art. 59 EuGVVO p. 1; Peiffer and Peiffer, 2016: Art. 59 VO [EU] Nr. 1215/2012 p. 17).

The formal modalities for the refusal of enforcement are roughly provided for in Chapter III, Section 3, Subsection 2, of the Brussels Ia Regulation (Art. 58 Brussels Ia Regulation); the concrete modalities, however, are specified by national law. In Austrian enforcement law, for example, a ground for refusal of enforcement can be raised by the means of an application for termination of the enforcement procedure according to Sec. 418(1) of the Austrian Enforcement Code (cf. Neumayr and Nunner-Krautgasser, 2018: 131).

If the payment of a sum of money was agreed on in the settlement (cf. Mayr, 2020: p. IV/198), the person entitled to payment also has the option of having the settlement certified as a European Enforcement Order (Brenn, 2010: Art. 58 EuGVVO p. 13; Kern, 2017: Art. 59 Brüssel Ia VO p. 2). In this case, not even an infringement of public policy constitutes a ground for the refusal of enforcement 
(Art. 5 of the Regulation on a European Order for Payment ${ }^{8}$; cf. Geimer, 2020: Art. 59 EuGVVO p. 16; Kern, 2017: Art. 59 Brüssel Ia VO p. 2).

\subsection{Special problems: Unknown measures and undetermined court settlements}

As is true with judgments, the cross-border enforcement of court settlements can also give rise to similar problems. For example, it is possible that the settlement contains measures not recognized by the law of the enforcing Member State. Under this scenario, Art. 54(1) Brussels Ia Regulation provides that that measure or order shall, to the extent possible, be adapted to a measure or an order known in the law of that Member State which has equivalent effects attached to it and which pursues similar aims and interests. A corresponding national implementing provision can be found in Austrian law in Sec. 404 of the Austrian Enforcement Code.

Due to different requirements for determining the enforcement titles in the individual Member States, it may also occur that the court settlement does not meet the necessary requirements of determination in the Member State of enforcement. While there are no explicit rules on the minimum requirements in this aspect, a certain degree of determination is an unwritten but teleologically necessary prerequisite for the Member State's obligation to enforce foreign enforcement titles (Geimer, 2020: Art. 39 EuGVVO p. 58). Therefore, if a supplement or concretization according to Art. 54 Brussels Ia Regulation is not possible, enforcement of the settlement may be refused in the requested Member State (Geimer, 2020: Art. 39 EuGVVO p. 58). In Austria, jurisdiction and literature argue that the (relatively strict) national standards regarding the determination of an enforcement title shall not apply on foreign enforcement titles $\left(\mathrm{OGH}^{9} 3 \mathrm{Ob}\right.$ 160/98w; 3 Ob 104/03w; Kodek, 2014: Art. 39 EuGVVO p. 12; Rassi, 2010: Art. 38 EuGVVO p. 7). If the title is still too vague (even after applying lower standards), however, the party seeking enforcement needs to raise an "action for completion of an enforcement title" according to Sec. 10 of the Austrian Enforcement Code (Burgstaller and Neumayr, 2002: Art. 38 EuGVO p. 7).

\footnotetext{
${ }^{8}$ Regulation (EC) No 1896/2006 of the European Parliament and of the Council of 12 December 2006 creating a European order for payment procedure (OJ L 399, 30. 12. 2006 p. 1).

${ }^{9}$ Oberster Gerichtshof (Supreme Court); the decisions of the Austrian Supreme Court can be accessed on the website https://www.ris.bka.gv.at/.
} 


\section{$5 \quad$ Recognition of court settlements?}

The question of the possible recognition of court settlements can be of great significance, because in some Member States court settlements may have legal effects (such as a res indicata effect) in addition to the effect of enforceability (cf. Geimer, 2020: Art. 58 EuGVVO p. 27). According to the prevailing doctrine (Kodek, 2014: Art. 36 EuGVVO p. 22; Mayr, 2020: p. IV/32; Neumayr, 2017: p. 3.896 and 3.906; for a deep analysis cf. Frische, 2007: 130-173), court settlements cannot be recognized within the scope of the Brussels Ia Regulation. This doctrine is based on the fact that court settlements do not constitute judgments according to Art. 2(a) Brussels Ia Regulation, so that the provisions on recognition (which explicitly refer to judgments) do not apply. This doctrine is also supported by the system-derived argument that the enforceability of court settlements is explicitly regulated in Art. 59 of the Brussels Ia Regulation, and that there is no reference to the applicability of the provisions on recognition in Art. 58 of the Brussels Ia Regulation. While these arguments are convincing for the recognition of effects like the (possible) res judicataeffect of a court settlement, recently some important voices have argued in favour of recognizing the effect of enforceability (Geimer, 2020: Art. 39 EuGVVO p. 1-9 and Art. 58 EuGVVO p. 27). In the light of this, recognition (at least of the effect of enforceability) could also be argued to fall within the scope of the Brussels Ia Regulation. It is noteworthy that other European regulations do provide for the recognition of court settlements. Both the Brussels IIa Regulation ${ }^{10}$ and the Regulation on Maintenance Obligations ${ }^{11}$ contain provisions on this (Art. 46 Brussels IIa Regulation; Art. 48(1) of the Regulation on Maintenance Obligations), so that all the possible effects of a court settlement may be transferred to other Member States (cf. Sengstschmied, 2010: Art. 46 EuEheKindVO p. 13-15). This can, again, ${ }^{12}$ create the above-mentioned problems regarding the scope of the regulations when the court settlement encompasses rights and legal relationships which, if settled separately, would fall within the scope of different European regulations. In practice, therefore, caution is advised if it is foreseeable that the court settlement may also have effects in other Member States.

\footnotetext{
${ }^{10}$ Council Regulation (EC) No 2201/2003 of 27 November 2003 concerning jurisdiction and the recognition and enforcement of judgments in matrimonial matters and the matters of parental responsibility, repealing Regulation (EC) No 1347/2000 (OJ L 338, 23.12.2003, p. 1).

${ }^{11}$ Council Regulation (EC) No 4/2009 of 18 December 2008 on jurisdiction, applicable law, recognition and enforcement of decisions and cooperation in matters relating to maintenance obligations (OJ L 7, 10.1. 2009, p. 1). ${ }^{12}$ Cf. chapter 3.2.
} 


\section{Conclusion}

Court settlements are among the most practical instruments of amicable dispute resolution; however, the explicit provisions for their cross-border enforcement are rather sparse within the Brussels Ia Regulation. This can cause complicated problems in some constellations; for example, where the settlement regulates rights and legal relationships that would fall within the scope of different European regulations. In practice, this does not seem to be an overly serious issue, especially since in most cases the parties willingly fulfill their obligations after an amicable settlement of the dispute. Some clarifications - for example with regard to the definition of a court settlement or the scope of application of the regulations in the case of comprehensive settlements - would nevertheless be desirable from a legal policy perspective.

\section{References}

Anzenberger, P. (2020) Der gerichtliche Vergleich (Wien: LexisNexis).

Brenn, C. (2010) in: Fasching, H. and Konecny, A. (editors) Kommentar zu den Zivilprozessgesetzen, 2nd edition, tome $\mathrm{V} / 2$ (Wien: Manz).

Burgstaller, A. and Neumayr, M. (2002) in: Burgstaller, A., Geroldinger, A., Neumayr, M. and Schmaranzer, G. (editors) Internationales Zivilverfahrensrecht (Wien: LexisNexis).

Dickinson, A. and Lein, E. (2015) The Brussels I Regulation Recast (Oxford: Oxford University Press).

Frische, T. (2006) Verfahrenswirkungen und Rechtskraft gerichtlicher Vergleiche - Nationale Formen und ihre Anerkennung im internationalen Rechtsverkehr (Heidelberg: C.F. Müller).

Geimer, R. (2020) in: Geimer, R. and Schütze, R. (editors) Europäisches Zivilverfahrensrecht, 4th edition (München: C.H. Beck).

Kern, C. (2017) in: Wieczorek B. and Schütze R. (editors) Zivilprozessordnung und Nebengesetze, 4th edition, tome XIII (Berlin: De Gruyter).

Klicka, T. (2015) in: Fasching, H. and Konecny, A. (editors) Kommentar zu den Zivilprozessgesetzen, 3rd edition, tome II/3 (Wien: Manz).

Kodek, G. (2014) in: Czernich, D., Kodek, G. and Mayr, P. (editors) Europäisches Gerichtsstands- und Vollstreckungsrecht, 4th edition (Wien: LexisNexis).

Kropholler, J. and von Hein, J. (2011) Europäisches Zivilprozessrecht, 9th edition (Frankfurt: Verlag Recht und Wirtschaft).

Leible, S. (2016) in: Rauscher, T. (editor) Europäisches Zivilprozess- und Kollisionsrecht EuZPO/EuIPR - Kommentar, 4th edition, tome I (Köln: Otto Schmidt).

Mankowski, P. (2016) in: Rauscher, T. (editor) Europäisches Zivilprozess- und Kollisionsrecht EuZPO/EuIPR - Kommentar, 4th edition, tome I (Köln: Otto Schmidt).

Mayr, P. (2020) Europäisches Zivilprozessrecht, 2nd edition (Wien: facultas).

Neumayr, M. (2017) in: Mayr, P. (editor) Handbuch des europäischen Zivilverfahrensrechts (Wien: Manz).

Neumayr, M. and Nunner-Krautgasser, B. (2018) Exekutionsrecht, 4th edition (Wien: Manz).

Peiffer, E. and Peiffer, M. (2016) in: Geimer, R. and Schütze, R. (editors) Internationaler Rechtsverkehr in Zivil- und Handelssachen (München: C.H. Beck). 
Rassi, J. (2010) in: Fasching, H. and Konecny, A. (editors) Kommentar zu den Zivilprozessgesetzen, 2nd edition, tome V/2 (Wien: Manz).

Schulze, G. (2017) in: Wieczorek, B. and Schütze, R. (editors) Zivilprozessordnung und Nebengesetze, 4th edition, tome XIII (Berlin: De Gruyter).

Sengstschmied, A. (2010) in: Fasching, H. and Konecny, A. (editors) Kommentar zu den Zivilprozessgesetzen, 2nd edition, tome V/2 (Wien: Manz).

Staudinger, A. (2016) in: Rauscher, T. (editor) Europäisches Zivilprozess- und Kollisionsrecht EuZPO/EuIPR - Kommentar, 4th edition, tome I (Köln: Otto Schmidt).

von Hoffmann, B. and Hau, W. (1995) Deutscher Prozeßvergleich kein Anerkennungshindernis nach Art. 27 Nr. 3 EuGVÜ, IPRax 1995, 217-218.

\section{About the author}

Dr. Philipp Anzenberger, Associate Professor at the Institute of Civil Procedure and Insolvency Law, University of Graz (Austria). 
